\title{
VISIBILITY, USABILITY AND ACCESSIBILITY OF POLISH E-COMMERCE WEBSITES FROM THE B2C SECTOR
}

\author{
Artur GĄSIORKIEWICZ \\ Faculty of Management \\ Warsaw University of Technology, 02-524 Warszawa, Poland \\ a.gasiorkiewicz@wz.pw.edu.pl
}

\begin{abstract}
In the time of rapid development of Internet technologies and changing competitive environment, one of the most significant ways of creation of the e-commerce endeavor value is the increase of the incoming traffic of the internet website and the level of its conversion into business goals. Undertaking activities form the scope of internet marketing and increase of the usability and accessibility of websites are supporting this cause. However, this issues being broadly described in the literature they still have limited applications in business practice. The article presents the most important factors influencing the scope and characteristics of internet traffic that depends on the internet website owners. Issues are illustrates with research of listed factors that were performed on selected e-commerce systems from the B2C sector in Poland.
\end{abstract}

Key words: e-commerce system, B2C sector, website, internet, visibility, "10 Usability Heuristics", usability and accessibility of website.

1

\section{Introduction}

Internet marketing issues are widely described in international literature and, more often, in national literature. Usually these are elaborations that are basing on traditional marketing concepts and are trying to adapt them for the needs of the new functioning conditions and focus of the needs of global enterprises [1, 12]. Additionally, even though they have considerable focus on the issues of internet advertising, they tend to pay little attention to the function of the enterprise's websites. Nevertheless many enterprises use their websites as the basic marketing communication channel with the market and its significance is even more considerable for enterprises with high level of virtualization.

The role of websites as the basic tool of marketing communication with internet customers becomes more and more popular among the authors of IT publications. They tend to point out the nature of websites, especially in the B2C sector, as IT systems that have a wide group of recipients, emphasizing the need to adjust their functionality and interface to the needs and requirements of the user [4]. J. Nielsen is said to be the founder of scientific research on the usability of websites, who, together with R. Molich, elaborated set of rules for the computer system interface design in 1990 [10]. These issues were later developed, by Nielsen and his associates, on the basis of analysis of the most frequent user interface errors in computer systems $[9,10]$. The result of Nielsen's work was the publishing of "10 Usability Heuristics", key rules of Human-Machine interaction, which were the foundation of further works on the usability of IT system interfaces, especially the internet websites.

Parallel to the issues of marketing and usability, the issues of website accessibility for the biggest possible number of users, regardless of their features or disabilities, as well as independent of the software and hardware they are using [13]. The concept of accessibility was introduced by the World Wide Web Consortium (W3C), which collects over 400 organizations, enterprises, government agencies and universities for all over the World, which deal with determination of writing and transferring of internet websites. Web Accessibility Initiative was created as part of the $\mathrm{W} 3 \mathrm{C}$ and aimed at providing website access for people with alternative abilities but also people using particular equipment, connections and software to access internet at work.

In case of e-commerce B2C systems, described in this article, website internet marketing, usability and accessibility issues are extremely important. They have a direct influence on the number of website users and their willingness to purchase and indirect influence on the level of sales income. 


\section{Incoming website traffic in relation to business goals}

Incoming website traffic can be described with two basic parameters. Fist on is the size of the traffic and the second one is conversion level to business goals ${ }^{1}$. Size of incoming internet traffic can be determined with the following parameters:

- determination of scope of the website for particular population in given time,

- determination of number of website displays in given time,

- determination of the number of unique users that display the website in given time,

- determination of the main site and sub-sites display number in given time.

The simplest way is to calculate website displays - for example with the website ${ }^{2}$ statistics systems - in particular period of time. Total number of displays of the main page corresponds to the number it was seen by the users, including different kinds of internet bots ${ }^{3}$. Some statistical systems are able to recognize the displays irrelevant form the business point of view and count only the ones realized by real website users ${ }^{4}$. However, such data, even though important for the website owner, is improper for the comparison of different websites. During each display, understood as continuous activity of the user at the website ${ }^{5}$, the user can browse through

\footnotetext{
1 „Conversion" concept in marketing describes the reaching of an advertising campaign goal through performance of particular activities by one of the receivers from the target group. Conversion can have the form of product purchase, registration in cooperation program, participation in promotional competition etc. Conversion is the purchase of a product by the customer and the conversion level is defined as the number of visits that end with a purchase, in relation to incoming internet traffic for the ecommerce websites of $\mathrm{B} 2 \mathrm{C}$ sector.

${ }^{2}$ Website statistical system is used to collect and analyze statistical data that concerns the website server incoming traffic. One of the most common statistical tools of such kind is the freeware Google Analytics.

${ }^{3}$ Internet bots are programs that automatically scan the content of websites. They operate as part of browsing systems (commonly known as internet browsers), internet folders and other information gathering systems. Such programs check the websites on regular basis in order to index them or update collected information. Another kind of internet bots is the validators that check the websites according to their consistency with specific technical demands. One of the examples can be the W3C Markup Validation Service, which checks the validity of the website source code. It can be found at: http://validator.w3.org/.

${ }^{4}$ That are not the internet bots.

${ }^{5}$ It is usually assumed that clicking in a next page of the website earlier than after 15-30 minutes is treated as part of the same
}

many different pages. Moreover the same user can be responsible for repetitive visits during the researched period of time. Therefore, considerable number of displays of the website does not have to correspond to the reach of the website ${ }^{6}$. That is why the most common factor to evaluate the popularity of the website is the number of unique users ${ }^{7}$ in particular time or - as an indirect solution - the number of visits generated by them. The ratio of number of unique users in relation to the total number of users of given population determines the reach of particular website in this population.

Reach of the website determines the brand recognition in given population, from the perspective of selling websites. It usually corresponds to the sales volume but it is not a relation that can be described with a simple mathematical formula. Incoming website traffic, even though it is valuable in case of websites that are an element of e.g. product campaign, is not a goal itself for e-commerce systems. Its conversion level into business targets is significant (sales in this case). Traffic that does not generate sales becomes a liability in the long-term perspective for the e-commerce website owner. On the contrary, relatively small traffic, which eventually leads to the purchase, can significantly influence the income level and proper margin modeling also means profit for the enterprise.

Factors that influence the incoming traffic level can be defined on the basis of user requirements analysis, which can lead to better fulfillment of user expectations. This approach is presented in the Table 1.

Website incoming traffic can be divided into initial and returning. Incoming traffic originates from the activities of new users of the website and the returning traffic is generated by the users, who are using the website again in given time ${ }^{8}$.

website display (session). Exceeding this time means that further activity is treated as next visit of the same user.

${ }^{6}$ Example illustrating this issue is the Megapanel PBI/Gemius research result from September 2008, which indicates that the highest number of visits - 9,811 billion - was reached in Poland by the nasza-klasa.pl, what corresponded to the first place. The fourth place was taken by the Google browser (little over 3 billion). However, Google websites have the biggest number of unique users (13,38 million), what corresponds to the reach of $85,87 \%$ of Polish internet users and nasza-klasa.pl website, with 8,25 million unique users has the $52,97 \%$ reach what places it at fourth place.

${ }^{7}$ One of the calculation methods of unique website users from given population is presented by Gemius SA, which specializes in research on internet. The documents can be found at: audyt.gemius.pl/docs/2006_09_19_white_paper_real_users.doc. ${ }^{8}$ Usually described on monthly basis. 
Table 1. Ways of initiating and fulfilling the needs in the internet purchasing process

(source: self study)

\begin{tabular}{|c|c|c|}
\hline User activities & Website owner activities & Effect \\
\hline website resources browsing & formulation of internet visibility & user interest \\
\hline entering the website & $\begin{array}{c}\text { formulation of usability } \\
\text { and accessibility of the website }\end{array}$ & $\begin{array}{c}\text { willingness to use the website } \\
\text { (felt by the user) }\end{array}$ \\
\hline browsing through the website & $\begin{array}{c}\text { formulation of pricing policy, } \\
\text { optimization of website's usability }\end{array}$ & $\begin{array}{c}\text { purchase willingness } \\
\text { formulation }\end{array}$ \\
\hline $\begin{array}{c}\text { adding products to cart } \\
\text { verification and finalization } \\
\text { of the transaction }\end{array}$ & $\begin{array}{c}\text { formulation of website's usability } \\
\text { and accessibility }\end{array}$ & $\begin{array}{c}\text { willingness to extend the shop- } \\
\text { ping and finalize transaction }\end{array}$ \\
\hline waiting for the package & $\begin{array}{c}\text { usability formulation and high quality } \\
\text { of post-sales support }\end{array}$ & satisfaction from the transaction \\
\hline
\end{tabular}

High ratio of the initial traffic with relation to the returning traffic, maintained for a longer period, can correspond to low loyalty of the website users, which signalizes the necessity to perform business or technical changes. Short-term increase of the ratio's value is usually the effect of intensive internet marketing campaigns, which result in the income of considerable number of new users in a short period of time. The volume of both the initial and returning traffic can be influenced by few user motivating factors that should be answered with relevant e-commerce activities, which model the basic business and technical features of the website.

The main motivation for the new user to enter the selling website is the search of particular product of interest in spotted offer. Opinion about the website, especially expressed by previous users ${ }^{9}$ and concerning the satisfaction from the service quality or feeling of added-value ${ }^{10}$, is also a crucial factor in the gathering of new users.

In case of returning traffic, website features and user satisfaction have greater meaning in user motivation to visit the website again. User of B2B sector e-commerce system motivating factors are presented in the Figure 1.

Increase of the traffic incoming to the website is performed mainly through the fulfillment increase of the user's needs and requirements, from the perspec-

\footnotetext{
${ }^{9}$ Totality of opinions, on given endeavor or its website, published and visible in the internet - defined as ,e-publicity”.

${ }^{10}$ Should not be treated as the price level - user satisfaction can originate from high functionality and usability or interesting content of the website.
}

tive of the website owner. The most important activity it this manner that leads to the increase of the initial traffic is reaching with the information about the website (offers, promotions etc.) and making the user form the focus group interested. It is also relevant in terms of returning traffic, even though in this case different reaching mechanisms are used (e.g. personalized "push" communication" ${ }^{11}$ ). All of these activities are located in the area of website internet visibility formulation. Apart from strictly business aspects, the assurance of the feeling of comfort during using of the website is equally important, for the size of returning traffic and the conversion level of the incoming traffic. Website usability and accessibility modeling activities are used to support this cause.

Website features that influence the incoming traffic of the e-commerce $\mathrm{B} 2 \mathrm{C}$ website are presented in the Figure 2.

Deliberations above are signaling the importance of internet marketing issues (in the scope of visibility modeling) as well as usability and accessibility as the factors that influence the size of website incoming traffic. It is important to mention that in case of selling websites, the activity optimization can significantly increase the sales income.

\footnotetext{
11 „Permission marketing”, is the e-mailings and newsletters sent to the customers registered in the database, who accepted to receive commercial information.
} 


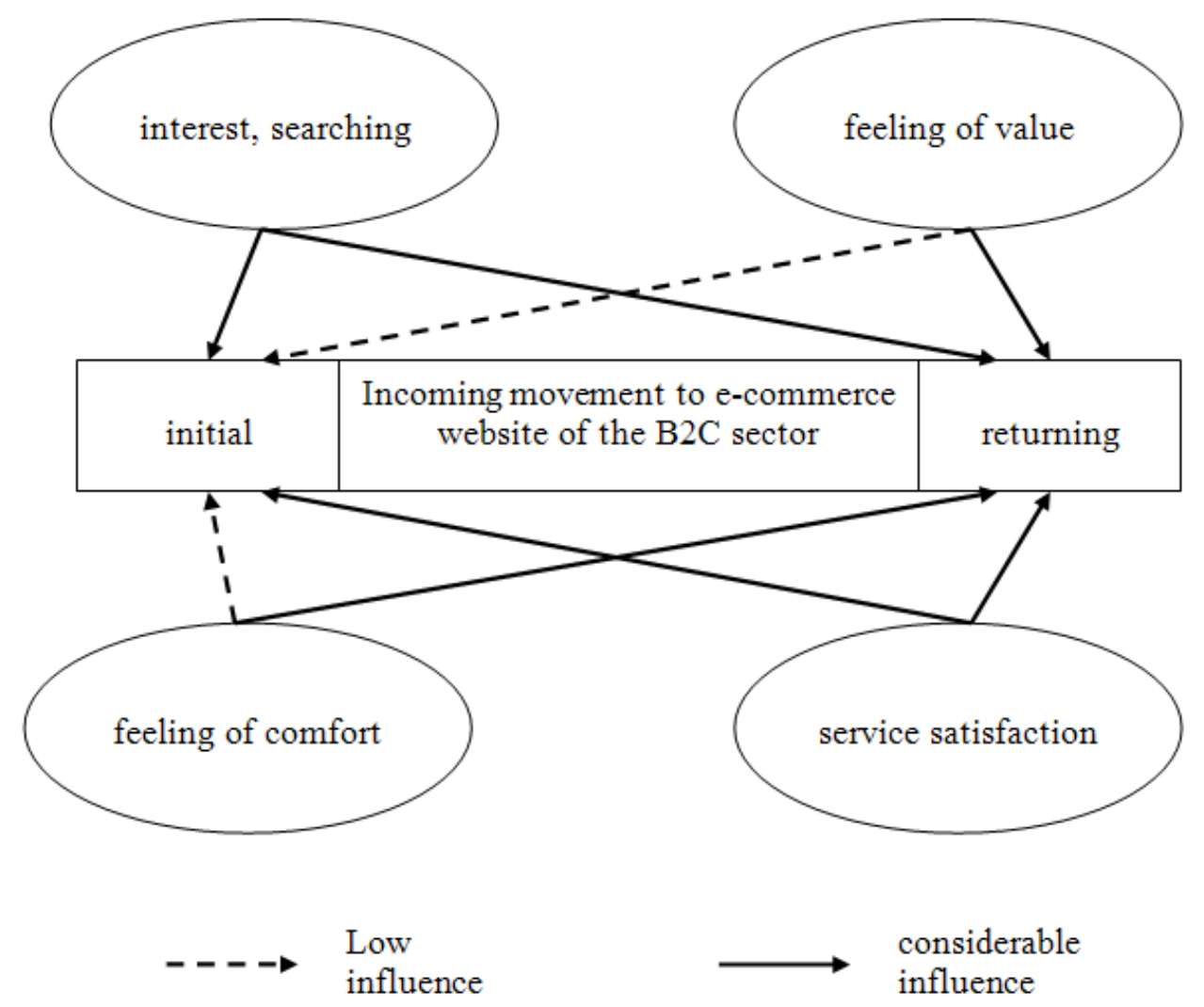

Figure 1. Factors motivating e-commerce system users in the B2C sector to visit the website (source: self study)

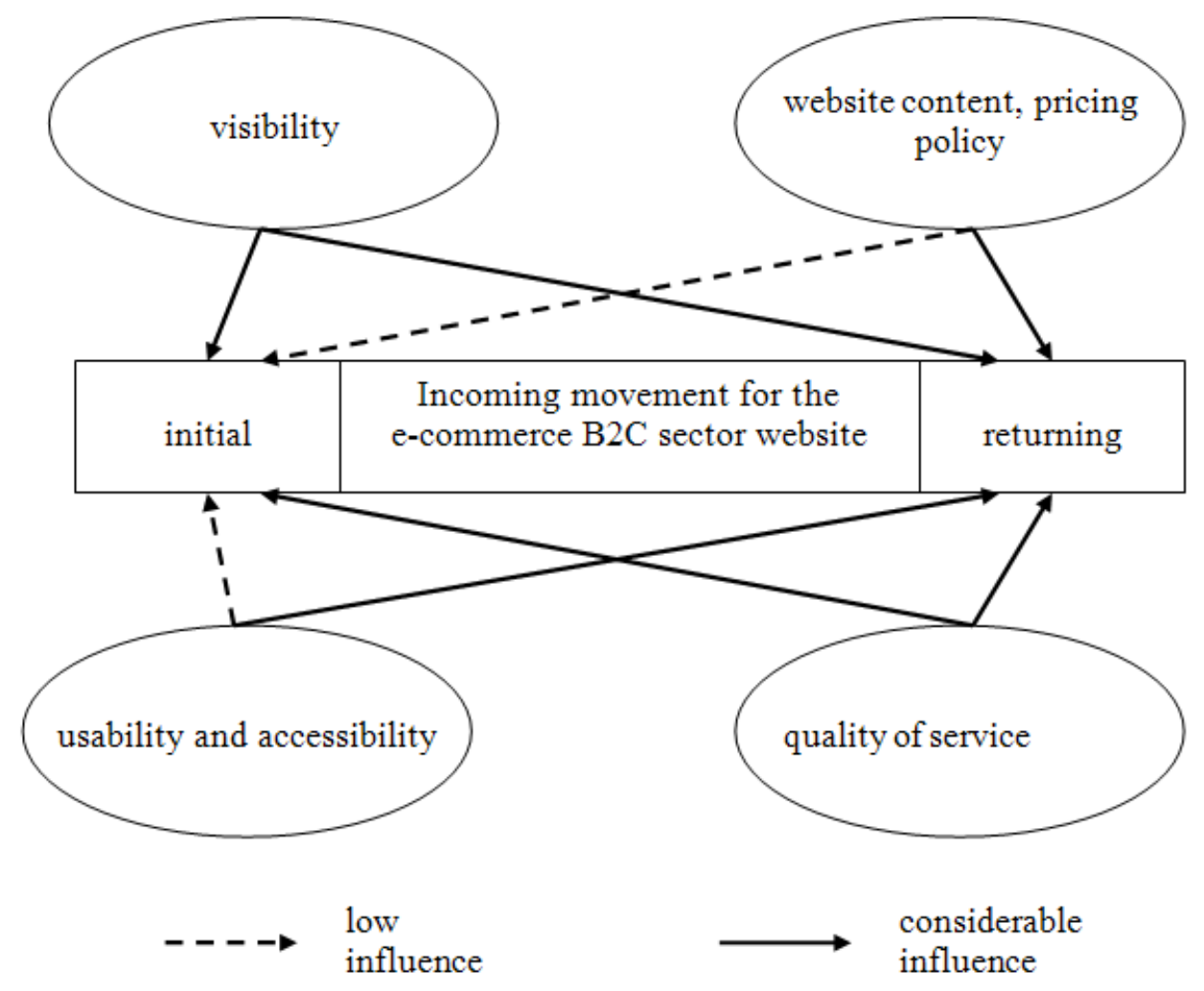

Figure 2. Features that influence the incoming traffic of the e-commerce B2C website (source: self study) 
One can use a simple example of the $\mathrm{X}$ enterprise to visualize this concept. With the assumption that the website of the $\mathrm{X}$ company notes 30 thousand visits per month, conversion level equals $2 \%$ and the average transaction level is $500 \mathrm{PLN}-$ it is possible to calculate that the monthly sales income is approximately 300000 PLN.

Table 2 presents the situation where the website optimization influences the sales volume of the X company, with the assumption of constant business conditions of the endeavor.

Table 2. Website optimization influence on the sales volume of the X company

(source: self study)

\begin{tabular}{|l|c|}
\hline $\begin{array}{l}\text { Monthly visits before } \\
\text { the website optimization }\end{array}$ & 30000 \\
\hline $\begin{array}{l}\text { Monthly visits after the activities } \\
\text { in the scope of internet marketing } \\
\text { that led to the increase of the website visibil- } \\
\text { ity - increase of } 50 \%^{12}\end{array}$ & 45000 \\
\hline $\begin{array}{l}\text { Monthly visits after the realization } \\
\text { of website accessibility activities - increase } \\
\text { of } 10 \%{ }^{13}\end{array}$ & 49500 \\
\hline $\begin{array}{l}\text { Conversion level after the realization } \\
\text { of usability increase activities - increase } \\
\text { of } 100 \%{ }^{14}\end{array}$ & $4 \%$ \\
\hline $\begin{array}{l}\text { Monthly sales increase after the website's } \\
\text { optimization }\end{array}$ & 990000 \\
\hline $\begin{array}{l}\text { Change of monthly internet sales income } \\
\text { from the X company after the optimization } \\
\text { of the website }\end{array}$ & $230 \%$ \\
\hline
\end{tabular}

Until recently the e-commerce industry treated the user registration as a form of validation of processed order and a tool that improved the loyalty of the customer and a convenience for the user during next purchases (due to the lack of need to input detailed data every time user is logged in). In described case the log-in form page was displayed to the user (if he was not al-

\footnotetext{
${ }^{12} 50 \%$ website visit increase is usually assumed as a realistic target for the visibility optimization activities campaign for small and medium e-commerce websites. Business practice indicates that in many cases it is possible to exceed this value.

${ }^{13}$ Estimation present in the literature speak of 3-20\% visit increase as a result of accessibility optimization of the website and adjustment to the needs of people with sight disabilities (approximately $10 \%$ of the users), users with slower internet connections (about $25 \%$ of users), elderly, less experienced, slow learning users (around $15 \%$ of users).

${ }^{14}$ Is the estimated average level of conversion increase as a result of website usability optimization according to the research of J. Nielsen, performed on the sample of 42 selling websites (www.useit.com/alertbox/roi-first-study.html).
}

ready logged-in) when he had accepted the content of the basket and pressed the „Checkout” button.

Customer behavior analysis indicated that many potential users have undertaken repetitive unsuccessful trials to log-in. Some of them started the password recovery procedure, but only $25 \%$ of these users were the registered website users. The rest of the customers either started another registration procedure (it was revealed that approximately $45 \%$ of the customers have more than one account) or cancelled resigned form the purchase. One of the proposed solutions was the resignation from the obligatory registration, leaving it only as one of the suggested solutions for the user. Apart from the $\log 0$ in form the "Continue" button was present, which allowed to perform the purchase without a registration in the website. This change led to the increase of order level by $45 \%$ and the annual sales increased by 300 million dollars. This example indicates the importance of the usability improvement activities for the e-commerce industry.

\section{Website visibility}

Internet website visibility is defined as the easiness of finding of the website by a potential user with relation to particular needs. It is important to mention that the user usually is not searching for the website but finds in with encountered links. Therefore the visibility of the website is dependent on the easiness of remembrance of its location in the internet as well as the easiness and frequency of links, leading to the website, spotting by potential users.

All activities connected with the increase of websites visibility can be divided into natural (organic) and commercial (paid). Natural activities are undertaken by the internet users, which usually unwittingly influence the visibility of the website through pasting of the links in many different websites and providing its useful content to other users of the internet.

Commercial activities include all forms of internet advertising. It is basically the advertisements in internet browsers, which contribute to the half of on-line advertising spending in the USA and $30 \%$ in Poland ${ }^{15}$, internet „display" ${ }^{\prime 16}$ advertising and permission marketing, realized through e-mail.

\footnotetext{
15 see: Money.pl.

${ }^{16}$ All forms of internet advertising connected with graphical creation - banners, layers in front of and behind the text, video advertisements etc.
} 


\subsection{Positioning in web search engines}

One of the most significant ways of improving the visibility of a website in the internet is the positioning ${ }^{17}$ in internet search engines. It results from two causes: firstly the internet search engines are a common source of knowledge for the internauts and secondly internauts while typing the search word are actually informing what they are looking for, what makes the internet advertising profiling much easier.

Usually the result of searching through particular phrase or expression through the web search engine provides two lists of results. First list consist of the natural results (also known as organic). In the assumption of web search engines creators, these results are neutral, based on the evaluation of the content and the natural popularity of the website, independent of the cooperation of business partners and web search engines. Second list, usually less exposed, consists of sponsored links, which are one of the forms of advertising in the internet.

Sometimes the sponsored links are also present at the first place of the natural results list, but are still highlighted as sponsored. In both cases the web search engine tries to present results, which best fit user's inquiry, but the list generating mechanisms are totally different. List of sponsored links is created on the basis of orders of advertisers, who pay in order for the link to be visible after typing one of the keywords into the search engine.

Algorithm that creates the natural results list is much more complex. Even though it is known mainly to the designers of the search engines, some guidelines and hints in the area of SEM (Search Engine Marketing) that allow to formulate general rules influencing the website positioning in the list of natural search results as a response to a typed keyword. Activities performed in order to get to the top of the result list are known as SEO (Search Engine Optimization). They consist of SO - Site Optimization and NP - Natural Placement [2].

Website optimization according to the search engines requirements is practically dependent on the site owner and his marketing and IT resources. It is based on the creation of valuable website content, according to both the users and search engine algorithms, and a number

\footnotetext{
${ }^{17}$ Positioning in web search engines is the totality of activities leading to reaching a relatively high position of the website in the list of search results displayed in response to particular keyword.
}

of technical activities that favor the position in the search list.

It is, for example, correctness of the website's source code, clear headlines set marked with HTML tags, using internal text links, presence of keywords in the text in suitable proportions etc.

Natural positioning, according to the creators of searching algorithms, is a process directly independent of the website publisher, based on an automatic evaluation of suitability of the site on the basis of the number of links from other internet websites. Thus it is obvious that the valuable content and functionality, with simultaneous high usability, should significantly increase the position in the search results.

In practical functioning of SEO, with relation to commercial websites, it is more commonly positioned with paid service and there is a dispute in the internet industry about the ethics of natural positioning activities inspired by business activities.

Constant race of competitors to reach the first place in the search lists is, on one hand, contributing to the creation of great number of artificial creations in the internet (catalogues, positioning blogs, positioning devices), with little intellectual value, used only to manipulate the natural search results, on the other hand, creates many legal disputes, where legal institutions only tend to follow the market reality [8].

In order to explain the issue of dishonest natural positioning, one needs to relate to the way of publishing links. Every ink published at websites consists of the destination address, object that is visually representing this object and other additional technical parameters.

For a common internet user as well as the majority of people responsible for the content of websites, it is natural to describe the links with a phrase that relates most accurately to the linked resources. Therefore if there will be a link to the Abecedex S.A. company present at the websites, than it will usually be described with the name of the company. If the link will lead to a particular spot of the website it is important, from the perspective of the author of the link, for the link to take a specific form e.g. Abecedex allegiance program. 


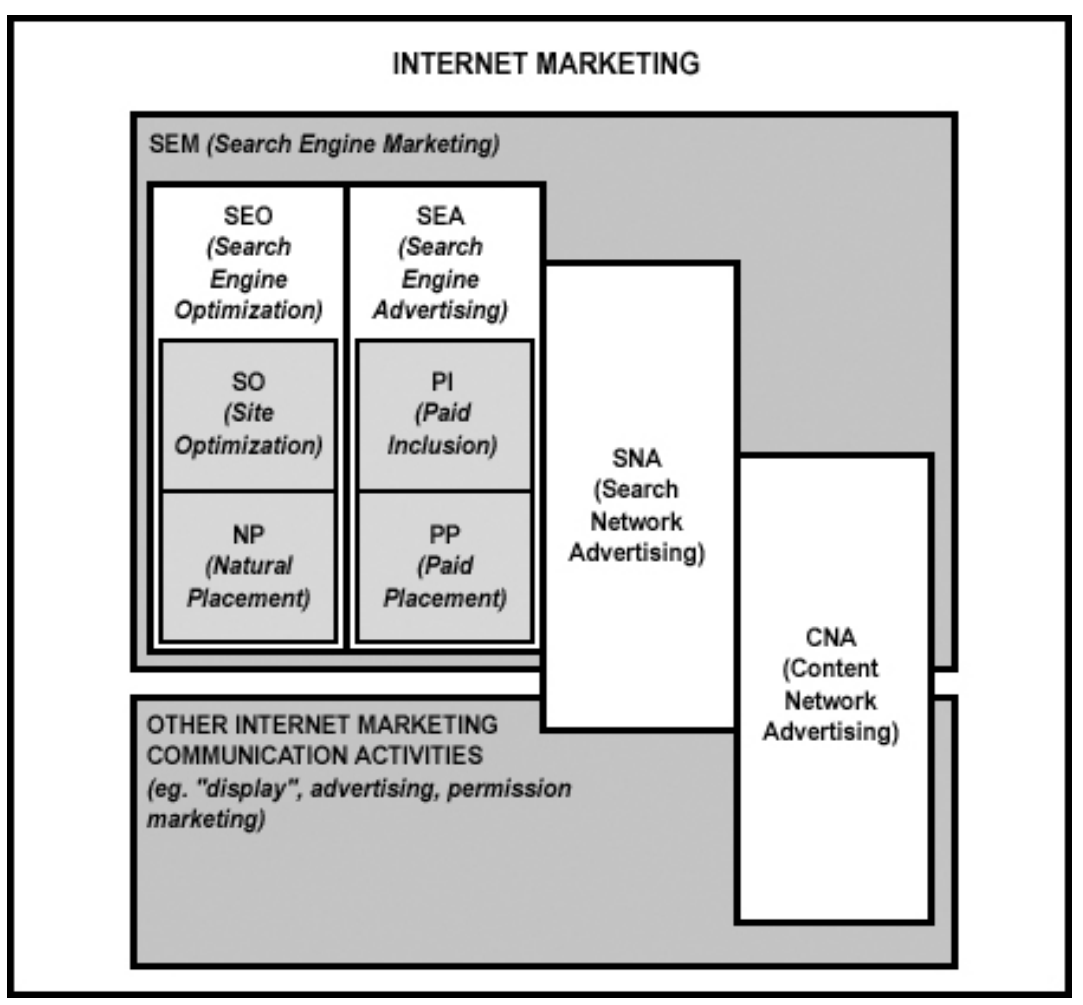

Figure 3. SEM partials in relation to the general internet marketing (source: self study)

Majority of the "incoming" links, described with a suitable phrase have a significant meaning for the website. It is a determinant of popularity, which increases the chance to get an important position in the search list. Power of links is more important if, according to the search engine, the linking pages are more significant. Number and power of links influences the visibility of the website and indirectly also its business value.

However, this mechanism tends to be used unethically not only due to the financial inspiration of the natural (in theory) mutual linking process in the net. The problem emerges when website links present in other pages are described in a way different from the one that the owner of the linked website would prefer. If this situation is copied, than it contributes to positioning of the website according to improper keyword or phrase.

Effects of hostile positioning were described in Polish media many times, when insulting phrases typed into a search engine led to the websites of ministers or members of the parliament. This phenomenon is a perfect example of the search engine algorithm manipulation.

Much more organized form of internet advertising is the SEA - Search Engine Advertising. Scope of activi- ties of SEA, contrary to SEO, is based directly on the commercial offer of search engines and creation of a financial liability towards them. There are two basic directions of such activities: PI (Paid Inclusion) paid inclusion of the website into the search engine and PP (Paid Placement) - paid positioning of the links leading to the website in the list of search results appearing after typing of certain keywords. In Polish internet most search engines are based on the PP business model (e.g. Google, Onet.pl, WP.pl, Live.com).

The most common web search engine using the PI model is the Yahoo. In case of paid positioning there are two main types of account settlement used. The most obvious and common global system is the PPC model (pay per click), which charges according to the number of clicks. Another very popular model is the CPM (cost per mille), meaning charging according to the number of displays of the advertisement.

Paid positioning in the search results is currently one of the most effective advertising forms, due to the fact that the user is provided with the sponsored link as a response to a particular sought phrase. Positioning of the website according to properly defined phrases not only increases its visibility, but also positively influences the website incoming traffic conversion. 
Common usage of web search engines in the modeling of website visibility is not random. According to different research on internet browsers, approximately 80 to $95 \%$ of the internauts uses the search engines. In Poland this number is equal to $88 \%$ and the practical monopolist in this area is the Google, which services over $95 \%$ of inquiries of Polish internauts ${ }^{18}$. However, mere presence of the website in search results does not guarantee its visibility. The position of the link is equally important. Kevin Lee from American Did-it.com presented in 2005 interesting results of research performed by the consortium of three companies - Eyetools, Enquiro and Did it.com, concerning the perception of searching results by the internauts. The author performed analysis and determined these areas of search results pages, which were most commonly viewed by the users and identified the spots that were clicked by the internauts searching for desired information.

According to the presented research results, users pay special attention to the first three search results. These research results are viewed by almost $100 \%$ of users. Fourth result is spotted by $85 \%$ of the users and the sixth result is spotted by less then half of the users. The most attention grabbing sponsored link, placed as fist at the standard Google layout (right column), draws the attention of over $50 \%$ of users but the fifth sponsored link draws attention of only $5 \%$ of the users. Other sponsored links are practically not visible and not spotted by the users. Internauts usually click on the first organic research results, including the highlighted sponsored ling, placed as the first one - above the organic results. Clicking on the sponsored links in the right column usually concern only the first link.

Research results emphasize the meaning of natural search result meaning for the visibility of the company in the internet. On the other hand, poor popularity of links generated as a result of paid SEM does not undermine their business effectiveness. Payment for the sponsored links at the research result page of the search engine (SEA) is based on the PPC model. It is important to emphasize the bonus mechanism of the sponsored links in the Google browser with a relatively high CTR (Click Through Ratio). This ratio determines the percentage of advertisement displays that resulted in the click of the user. Reaching of 3,5\% and over CTR ratio level gives the chance to display the results directly above the organic search.

\footnotetext{
${ }^{18}$ Gemius SA, „gemiusTraffic, 24.02.2009 - 02.03.2009” research.
}

Connection of SEA and SEO methods is the most effective in the SEM marketing, what was indicated by the practice. The main advantage of paid SEM is the possibility of getting immediate and reliable effects. It is extremely important in case of new endeavors. Sometimes it takes few months of waiting time before the page is indexed and the website position is built up in the natural search results page. However, natural positioning in the conditions of competitive rivalry and high popularity of keywords is not always as effective as the website owner expects.

\subsection{Other methods of internet website visibility formulation}

Relatively new, but efficient, method of visibility formulation in the internet is the use of the context advertising mechanisms. These mechanisms are listed as SEM tools mainly due to the fact, that the primary organizers of these systems are the leading web search engines. Modern context advertising market is rapidly developing and more and more companies provide such services. Their functioning is similar to the functioning of adserver systems ${ }^{19}$. Basic difference is the provision of an advertisement adequate to the content of the actual partner website content and not the specifics of the receiver group. Context advertisement systems are getting considerable popularity, due to the fact that they allow the cooperation for even the smallest advertisers and publishers ${ }^{20}$, automatically directing the advertisements to suitable websites with the setting of accounts in PPC system.

In recent years the total internet advertisement spending budgets are decreasing for the classic and modern "display" type advertisements. However it does not mean the radical decrease of the role of these most aggressive, but also most creative, types of visibility formulation. They are remembered and recognizable by the internauts. It is important to mention that the most aggressive advertisements (pop-up, pop-under, top layer) are becoming less popular in favor of video advertisements and modern banner forms (billboard, skyscraper).

\footnotetext{
${ }^{19}$ Systems, which have the publisher website advertisement emission, are controlled by the owner of the advertising company.

${ }^{20}$ In classical adserver systems the condition of website participation in the advertising network is the reaching of the level of 50-100 thousand visits per month. In case of context advertising systems, usually there are no limitations.
} 
Serious meaning in the creation of internet website visibility is also the effect of the permission marketing activities. They include all forms of commercial communication with the customer that is realized, after his approval, through electronic channels. The nature of this kind of advertising causes that it is mainly used to support the contact with the customer and periodically remind about the website and its content.

Summing up the deliberations about internet visibility it is important to mention that it dependent not only on the used forms of internet advertising. All other activities of the enterprise in the internet also contribute to this visibility that result in links popularization e.g. registration in branch catalogues, price comparison systems, virtual shopping malls, internet auctions etc.

\section{$4 \quad$ Website usability}

Usability is the measure of effectiveness and satisfaction brought with the product that is used to realize certain targets by particular users ${ }^{21}$. Little less formal but also very accurate definition is proposed by S. Krug, usability expert, which works for global brands like: Apple, Netscape, AOL and the author of a popular guide about website usability. He claims that usability is when "something is doing its job so that the person with medium (or even low) abilities and experience can use it according to the intentions of its creator and without the feeling of helplessness" [6]. This general definition proves that usability, with relation to websites, consists of many factors, among which the following are most popular:

- easiness to learn, the degree to which inexperienced users can perform easy tasks at the website,

- usage efficiency, the pace with which an advanced user realizes complex tasks with the system,

- easiness to remember, the degree to which the user who formerly have used the system can use it again without the necessity to learn,

- frequency and weight of errors,

- level of subjective user satisfaction ${ }^{22}$.

The list above indicates that the term "usability" should not be mistaken with, commonly used in IT terminology, "functionality". Second one is used to name the totality of functions realized through the IT system. "Usability" is a more complex concept, which includes

\footnotetext{
${ }^{21}$ ISO 9241-11 norm.

${ }^{22} \mathrm{http}: / /$ www.usability.gov/basics/whatusa.html.
}

IT issues and other like business, social, psychological, ergonomic etc.

Starting point for the usability designing and analysis should be the article by J. Nielsen "The 10 Usability Heuristics" mentioned in the beginning of the article (see Table 3).

Remaining consistent with the demands of usability of websites requires the performance of regular INTERNET research, both in the design phase as well as the implementation and exploitation. There are many usability researching methods, although some of them require special equipment.

Quite recently the "eyetracking" method, which studies the user perception of particular website and identifies the areas that are beyond his sight scope, was very popular. Modern research is focusing on the user brainwave pattern analysis, which allows measuring the satisfaction level of the user. Despite of the direction of the usability science development directions, some of its rules remain unchanged. For example the research list, which are used at the particular stages of the website exploitation (see Table 4).

Part of the listed research requires considerable financial resources with relation to the project (usability issues usually consume $5-10 \%$ of new project's budgets). However, it is crucial to remember that the simplest research, which allows seeing all the basic issues with the usability of the website, are affordable even for small enterprises, with limited investment budgets.

One of the basic research possible to conduct personally perform with a small group of users ${ }^{23}$ is the, so called, Krug's test. The research is based on displaying of a random website to the users and asking to provide answers for the following questions:

- what website is it?

- what page am I on?

- what are the main categories?

- what are the selection options at this level?

- where are we in relation to the website structure?

- how can I search for something?

Results coming from users' answers allow identifying the most significant issues with website usability.

\footnotetext{
${ }^{23}$ Suggested number is 3-5 users. Such methods, according to the author, are sufficient to determine $85 \%$ of current website issues.
} 
Table 3. , The 10 Usability Heuristics” J. Nielsena

(source: www.useit.com by J. Nielsen)

\begin{tabular}{|c|c|}
\hline Heuristics & Explanation \\
\hline Visibility of system status & $\begin{array}{l}\text { The system should always keep users informed about what is going on, } \\
\text { through appropriate feedback within reasonable time. }\end{array}$ \\
\hline $\begin{array}{l}\text { Match between system and the } \\
\text { real world }\end{array}$ & $\begin{array}{l}\text { The system should speak the users' language, with words, phrases and } \\
\text { concepts familiar to the user, rather than system-oriented terms. Follow } \\
\text { real-world conventions, making information appear in a natural and logi- } \\
\text { cal order. }\end{array}$ \\
\hline User control and freedom & $\begin{array}{l}\text { Users often choose system functions by mistake and will need a clearly } \\
\text { marked "emergency exit" to leave the unwanted state without having to go } \\
\text { through an extended dialogue. Support undo and redo. }\end{array}$ \\
\hline Consistency and standards & $\begin{array}{l}\text { Users should not have to wonder whether different words, situations, } \\
\text { or actions mean the same thing. Follow platform conventions. }\end{array}$ \\
\hline Error prevention & $\begin{array}{l}\text { Even better than good error messages is a careful design which prevents } \\
\text { a problem from occurring in the first place. Either eliminate error-prone } \\
\text { conditions or check for them and present users with a confirmation option } \\
\text { before they commit to the action. }\end{array}$ \\
\hline Recognition rather than recall & $\begin{array}{l}\text { Minimize the user's memory load by making objects, actions, and options } \\
\text { visible. The user should not have to remember information from one part } \\
\text { of the dialogue to another. Instructions for use of the system should be } \\
\text { visible or easily retrievable whenever appropriate. }\end{array}$ \\
\hline Flexibility and efficiency of use & $\begin{array}{l}\text { Accelerators - unseen by the novice user - may often speed up the interac- } \\
\text { tion for the expert user such that the system can cater to both inexperi- } \\
\text { enced and experienced users. Allow users to tailor frequent actions. }\end{array}$ \\
\hline Aesthetic and minimalist design & $\begin{array}{l}\text { Dialogues should not contain information which is irrelevant or rarely } \\
\text { needed. Every extra unit of information in a dialogue competes with } \\
\text { the relevant units of information and diminishes their relative visibility. }\end{array}$ \\
\hline $\begin{array}{l}\text { Help users recognize, diagnose, } \\
\text { and recover from errors }\end{array}$ & $\begin{array}{l}\text { Error messages should be expressed in plain language (no codes), precise- } \\
\text { ly indicate the problem, and constructively suggest a solution. }\end{array}$ \\
\hline Help and documentation & $\begin{array}{l}\text { Even though it is better if the system can be used without documentation, } \\
\text { it may be necessary to provide help and documentation. Any such infor- } \\
\text { mation should be easy to search, focused on the user's task, list concrete } \\
\text { steps to be carried out, and not be too large. }\end{array}$ \\
\hline
\end{tabular}

Other very popular type of research is the user tests, which are based on performance of a particular website usage scenario. However, such research requires the help of an expert, who will objectively, on the basis of knowledge, experience and possible focus group research, determine the proper test scenario. This research will brutally reveal all the shortcomings of the system, which hidden from the website owner, usually contribute to the resignation of the user from the services of particular website.

Currently there is plenty of high quality foreign literature that deals with website usability. The creation and development of the Web 2.0 idea, concerning website usability, contributed to the existence of such literature. Website design with high usability level is realized with the use of UCD (User Centered Design) methodology, which eliminates the possibly huge number of issues connected with website implementation.

Owners of commercial websites still underestimate are taking the usability issues. They think that finding the solution and acceptance are strictly on the side of the user. However, in highly competitive environment that is created by the internet, users do not hesitate to find alternative solutions, which are better in fulfillment 
of their needs. It is important to emphasize that website usability increase gives the chance to improve the impact of internet activities.

Table 4. List of research used to model website usability

\begin{tabular}{|c|c|}
\hline Stage & Research \\
\hline Analysis & $\begin{array}{l}\text { brainstorm, questionnaire (quanti- } \\
\text { tative research), qualitative re- } \\
\text { search (user interviews), focused } \\
\text { group interview, competition anal- } \\
\text { ysis, case studies, personas }{ }^{24} \text {. }\end{array}$ \\
\hline Designing & $\begin{array}{l}\text { prototyping, card sorting }{ }^{25} \text {, re- } \\
\text { quirements analysis (e.g. legal, } \\
\text { functional). }\end{array}$ \\
\hline Implementation & $\begin{array}{l}\text { A/B tests, heuristic analysis, user } \\
\text { tests. }\end{array}$ \\
\hline Exploitation & $\begin{array}{l}\text { questionnaire (quantitative } \\
\text { research), qualitative research (user } \\
\text { interviews), user tests, eyetracking, } \\
\text { clicktracking, web-mining }{ }^{26} \text {, } \\
\text { requirements analysis (e.g. legal, } \\
\text { functional, accessibility). }\end{array}$ \\
\hline
\end{tabular}

According to J. Nielsen's research ${ }^{27}$, usability can lead even to $100 \%$ of sales increase, $150 \%$ of incoming traffic increase (measured by the number of displays) and also improvement of many other business parameters of the website.

\section{Website accessibility}

World Wide Web Consortium (W3C) ${ }^{28}$ defines the accessibility of the website as the degree to which it can be perceived, understood and browsed by all users, independent of their characteristics of disabilities as well as the features of software and hardware used by them.

\footnotetext{
${ }^{24}$ Research based on the creation of focus group user archetypes in order to better understand their needs.

${ }^{25}$ The method of grouping, naming and information relevance hierarchy creation, with the use of the focus group.

${ }^{26}$ Data mining domain adjusted to data specifics originated form websites and their statistics systems, considering e-commerce analytical needs. It is used for e.g. searching of characteristic user website exploring patterns, link suggestions according to revealed focus group, presentation of suitable advertising banners, estimation of purchase probability etc.

${ }^{27} \mathrm{http}: / / \mathrm{www} \cdot$ useit.com/alertbox/roi-first-study.html.

${ }^{28} \mathrm{http}: / /$ www.w3.org/WAI/intro/accessibility.php.
}

The effect of W3C activities, in the scope of network accessibility, is for example the elaboration of international internet content accessibility guide called „Web Content Accessibility Guidelines 2.0". Its major part was adopted in the EU directive eEurope2002, on the basis of which all organizational units of EU countries are obliged to provide access to their websites without the discrimination of the users. United States issued the Rehabilitation Act, with the Section 508 obliges public institutions to providing the access to their informational websites electronic services.

Accessibility elements are also included in several norms concerning internet website design e.g. PKNCEN/CWA 15554:2007(U).

In national economical practice the issue of website accessibility is usually omitted, usually due to budget limitations for the realization of internet projects and limited knowledge about W3C initiatives.

It is important to emphasize that website accessibility is not only the possibility of usage for people with alternative abilities and disabilities, but also:

- reaching and finding bigger group of receivers (including elderly people),

- reaching demanding users, which use modern mobile platforms or modern software,

- gaining better positions in web search engines (websites with higher accessibility are positioned higher by the searching bots),

- creation of the positive image of the enterprise ${ }^{29}$.

\section{Examples of $\mathrm{V}-\mathrm{U}-\mathrm{A}$ research}

The example of practical application of presented deliberations is the performance of the visibility, usability and accessibility study of three shop websites with domestic appliances by the author, selected from ten of the biggest of such websites in Poland. The V-U-A research method was used in this elaboration (Visibility - Usability - Accessibility). Partial research areas in used methodology are collected in the table 5 .

The following websites were subjected to the research:

- Agito.pl (http://www.agito.pl),

- Neo24.pl (http://www.neo24.pl),

- Electro.pl (http://www.electro.pl).

\footnotetext{
${ }^{29}$ www.energa.pl/accessibility/dlaczego_dostepnosc.xml.
} 
Table 5. V-U-A research criteria

\begin{tabular}{|c|c|c|c|}
\hline \multicolumn{4}{|c|}{ V-U-A research } \\
\hline Research area / sub-area & Evaluation scale & Partial weight & Area weight \\
\hline Visibility study & $0-6$ & - & \multirow{4}{*}{0,4} \\
\hline visibility in Google.pl & $0-6$ & 0,5 & \\
\hline website reach & $0-6$ & 0,3 & \\
\hline $\begin{array}{l}\text { visibility and e-PR of the websites in } \\
\text { selected related e-commerce websites }\end{array}$ & $0-6$ & 0,2 & \\
\hline Usability study & $0-6$ & - & \multirow{3}{*}{0,4} \\
\hline $\begin{array}{l}\text { usability study based on the scenario of } \\
\text { the website usage }\end{array}$ & $0-6$ & 0,5 & \\
\hline expert usability analysis & $0-6$ & 0,5 & \\
\hline Accessibility study & $0-6$ & - & \multirow{3}{*}{0,2} \\
\hline $\begin{array}{l}\text { accessibility study at the level } 1 \text { of } \\
\text { WCAG W3C with Cynthia validator }\end{array}$ & $0-6$ & 0,6 & \\
\hline $\begin{array}{l}\text { research on the main improvements } \\
\text { triad in the scope of accessibility - } \\
\text { expert analysis }\end{array}$ & $0-6$ & 0,4 & \\
\hline
\end{tabular}

\subsection{Visibility study}

Visibility study consists of three basic partial studies. First one concerns the visibility of researched websites in the Google.pl web search engine according to selected tags and phrases. The intention behind the selection of Google search engine is its high popularity in the internet (services approximately $95 \%$ of internet search engines enquiries in Poland) and high meaning for the websites indexed in it. Second partial study concerns the size and changes of the website reach during three months before the research was started. Third study dealt with visibility and opinions (e-PR) of the websites in selected Polish e-commerce websites.

\section{Website visibility study in the Google.pl}

Website visibility study in Google.pl search engine was performed in two steps. First one, based on qualitative research on 11 person group of test users, established the list of the most common search phrases, which would be used to perform the potential purchase of:

- dishwasher,

- LCD TV set.

Initial study indicated that users from the test group would use the following phrases and keywords:

- „AGD - domestic appliances”, „dishwashers”,

- „RTV”, „LCD TV set”.

Further part of the research included searching of the websites with the use of determined phrases in order to establish the visibility of the researched websites in the Google search engine. Research results are presented in the table 6 . The table presents: place of the website in the search results after typing of the keyword (or phrase) in organic results / place of the website in the search results after typing of the keyword (or phrase) in sponsored links.

Table 6. Website position in the search engine results in Google.pl after typing of specific phrase (natural / sponsored results)

\begin{tabular}{|l|c|c|c|}
\hline Phrase / website & Agito.pl & Neo24.pl & Electro.pl \\
\hline „AGD” & $0 / 0$ & $0 / 3$ & $21 / 0$ \\
\hline „dishwashers” & $0 / 0$ & $0 / 0$ & $19 / 0$ \\
\hline „RTV” & $0 / 0$ & $0 / 4$ & $4 / 0$ \\
\hline „LCD TV set” & $0 / 0$ & $0 / 0$ & $9 / 0$ \\
\hline
\end{tabular}

„0" digit indicates that the website was not visible in first five search results (in case of organic research) and not visible at the first page of the search engine (in case of sponsored links).

Research results indicate that Agito.pl has practically no visibility in the Google search engine, both in natural and sponsored links. Neo24.pl also is not included in the first five natural research results, although it is in one of the exposed positions in sponsored links, displayed after typing the phrases: „AGD” and „RTV”.

The highest visibility is reached by the Electro.pl website, which is shown at the first place of natural search results in Google, answering the inquiry for the phrase "RTV" and "LCD TV set". It is also present in second and third page of the natural results after typing the "AGD" and "dishwashers" keywords. Website is not visible in sponsored links. 
The result of visibility analysis in the Google.pl search engine resulted in the following score for the selected websites:

- Agito.pl - 0 points,

- Neo24.pl - 2 points,

- Elektro.pl - 4 points.

\section{Website reach research}

Data from the analytical website Alexa.com and the data from the research company website Gemius Ranking.pl were used in the research of website reach. Table 7 collects the results the traffic research of researched websites during the period of 10.2008 01.2009 .

Agito.pl website was determined as the website with the largest reach, according to performed research.
The reach of the website is three-times larger than he one of Neo24.pl. At the same time, the 356 position in the national website statistics indicates that the brand is well known among Polish internauts. Detailed research, however, reveals some unfavorable tendencies. Agito.pl slightly decreased the number of visits in last three months, whereas the competition increased its reach (Neo24.pl by 56\%, Electro.pl by $68 \%$ ).

The tendency, unfavorable for the leader, is also the decrease of the user activity and engagement in website pages browsing, which decreased in last three months by $9 \%$. Competition noted growth in this matter (respectively by $13 \%$ and $8 \%$ ) and the absolute winner in the number of browsed pages is the Neo24.pl website.

\begin{tabular}{|c|c|}
\hline $\begin{array}{l}\text { agd } \\
\text { ( ) Szukaj w Internecie } \bigcirc \mathrm{Sz}\end{array}$ & $\begin{array}{c}\text { Szukaj } \\
\text { aj na stronach kategorii: język polski }\end{array}$ \\
\hline Wyniki 1 - 10 spośród około $27,700,000$ & pytania agd. (Zn \\
\hline $\begin{array}{l}\text { AGD } \\
\text { 123AGD.pl/Sklep-AGD Ainki sponsorowane } \\
\text { Swietna obsluga, rewelacyjne ceny! } \\
\text { Agd - RTV Euro AGD } \\
\text { Euro.com.pl/AGD Najniższe ceny tylko u nas. } \\
\text { Zobacz promocje i zamów! }\end{array}$ & $\begin{array}{l}\text { NEO24.PL w Warszawie } \\
\text { Kup w internecie, zapłać gotówką. } \\
\text { Taniej nie bẹdzie. } 6000 \text { produktów. } \\
\text { www.neo24.pl } \\
\text { Mazowieckie }\end{array}$ \\
\hline $\begin{array}{l}\text { Naczynia Valira Korkmaz } \\
\text { www.piekniegotuj.pl Eleganckie wyposażenie kuchni } \\
\text { Wyłączny importer w Polsce. } \\
\text { Otomedia - Agd, Rtv, LCD, kuchenki, lodówki. } \\
\text { kina domowe, pralki ... } \\
\text { Sklep internetowy otomedia.pl. W ofercie najwyższej } \\
\text { klasy sprzęt AGD i RTV: kuchenki, lodówki, kina } \\
\text { domowe, telewizory, LCD. Zapraszamy na zakupy do } \\
\text { naszego .... } \\
\text { otomedia.pl/ - 57k - Kopia - Podobne strony }\end{array}$ & $\begin{array}{l}\text { Agd } \\
\text { Porównaj ceny. } \\
\text { Sprawdź opinie, recenzje i forum. } \\
\text { www.ceneo.pl } \\
\text { AGD RTV - Topmarket } \\
\text { Sprawdź nasze ceny, } 0225771144 \\
\text { Warszawa - Promocyjna Dostawa } \\
\text { www.Topmarket.pl } \\
\text { Duże AGD w redcoon } \\
\text { AGD w pikantnie niskich cenach }\end{array}$ \\
\hline
\end{tabular}

Figure 4. Neo24.pl website visibility in sponsored links for the „AGD” search phrase (source: Google.pl)

Table 7. Results of the traffic analysis of researched websites during $10.2008-01.2009$

\begin{tabular}{|l|c|c|c|}
\hline \multicolumn{1}{|c|}{ Researched value } & Agito.pl & Neo24.pl & Electro.pl \\
\hline Website reach in the global population of internauts & $0,00347 \%$ & $0,00076 \%$ & $0,00116 \%$ \\
\hline Monthly visit number & 90908 & 19910 & 30390 \\
\hline Change of reach in previous 3 months & $-1 \%$ & $+56 \%$ & $+68 \%$ \\
\hline Statistical place in the Polish website ranking & 356 & 1361 & 1160 \\
\hline Number of viewed website pages during single visit & 4,93 & 6,00 & 3,91 \\
\hline $\begin{array}{l}\text { Change in the number of viewed website pages during } \\
\text { previous 3 months }\end{array}$ & $-9 \%$ & $+13 \%$ & $+8 \%$ \\
\hline
\end{tabular}


It is important to mention that further study show little probability of relation between the number of browsed pages and the navigation solutions used in the website - every website required 2 clicks to reach the desired group of products (and reloading of the website).

Agito.pl was awarder with the highest note in the visibility study. Identical score was given to Neo24.pl and Electro.pl. Even though the first site notes smaller number of visits, larger number of pages is browsed during each visit (therefore the engagement of the user in website browsing is more considerable). The marks awarded in the partial research are:

- Agito.pl-5 points,

- Neo24.pl-3 points,

- Elektro.pl-3 points.

\section{Construction of visibility and website e-publicity in selected e-commerce related websites (Allegro.pl, Opineo.pl, Ceneo.pl)}

This part of the research was used to determine the visibility of researched websites usually connected with internet users related with e-commerce. Websites, with the highest visibility in the following groups, were selected: market organizer, e-commerce systems opinion aggregator, price comparison systems. On the basis of Polish website reach study the following sites were selected: Allegro.pl, Opineo.pl and Ceneo.pl.

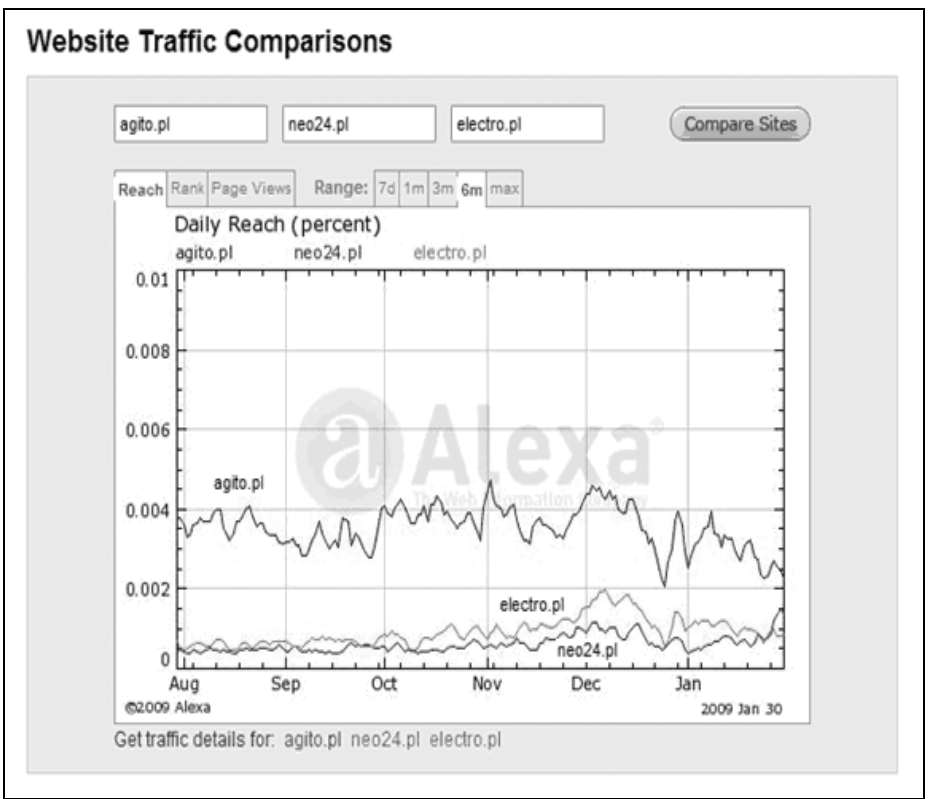

Figure 5. Reach of researched websites during 08.2008-01.2009 (source: Alexa.com)

\begin{tabular}{|c|c|c|c|}
\hline \multicolumn{4}{|c|}{$\begin{array}{l}\text { Reach for Agito.pl: (2) } \\
\text { Percent of global Internet users who visit this site }\end{array}$} \\
\hline Yesterday & 1 wk. Avg. & 3 mos. Avg. & 3 mos. Change \\
\hline $0.0023 \%$ & $0.00242 \%$ & $0.00347 \%$ & $1 \%$ \\
\hline \multicolumn{4}{|c|}{$\begin{array}{l}\text { Traffic Rank for Agito.pl: (?) } \\
\text { Alexa traffic rank based on a combined measure of page views and users (reach) }\end{array}$} \\
\hline Yesterday & 1 wk. Avg. & 3 mos. Avg. & 3 mos. Change \\
\hline 45,926 & 41,381 & 24,875 & 161 \\
\hline \multicolumn{4}{|c|}{$\begin{array}{l}\text { Page Views per user for Agito.pl: (2) } \\
\text { The number of unique pages viewed per user per day for this site }\end{array}$} \\
\hline Yesterday & 1 wk. Avg. & 3 mos. Avg. & 3 mos. Change \\
\hline 4.6 & 5 & 4.93 & $9 \%$ \\
\hline
\end{tabular}

Figure 6. Changes in the statistics of Agito.pl during 10.2008-01.2009 (source: Alexa.com) 
Neo24.pl has the highest visibility among the researched websites. At the same time the website makes the worst impression with relation to e-publicity. However, the marks posted by the users are relatively high, even though the number of negative opinions is considerably higher than in the websites of the competition.

It is important to mention that negative opinions are usually with similar content (especially focusing on the difficulty to contact with the e-commerce website employees), what makes them even more significant.

It is also important to emphasize that $6,4 \%$ of negative and neutral comments in Allegro.pl 10\% in Opineo.pl considerably undermines the reliability of the seller ${ }^{30}$.

Electro.pl is definitely receiving the best marks from the internet users among all of researched websites. Even though the website is not performing any additional sales with the use of Allegro.pl, its scale and scope is enough for effective individual performance. It is important to mention that in Opineo.pl and Ceneo.pl the Electro.pl website collected the biggest number of comments (what indicates a relatively high level of sales), with only $2 \%$ of negative and neutral comments.

In this part of research the highest mark was awarded to Electro.pl, which, even though it is not visible in Allegro.pl (probably due to the specialized sales with self e-commerce system and high order level), has the biggest number of comments in Ceneo.pl and Opineo.pl, with the highest amount of positive comments.

Agito.pl and Neo24.pl were evaluated similarly. In case if Neo24.pl one can speak of higher visibility, due to the use of the Allegro.pl action platform for current operations, even though the relatively high level of negative comments is decreasing the credibility of the website.

The marks awarded in the partial research are:

- Agito.pl -3 points,

- Neo24.pl-3 points,

- Elektro.pl -4 points.

Total evaluation with the consideration of weights awarded in the visibility $(\mathrm{V})$ research is as follows:

- Agito.pl - 1,8 points,

- Neo24.pl-2,5 points,

- Elektro.pl-3,7 points.

\footnotetext{
${ }^{30}$ Share of positive comments in total number of comments for the transactions below $98 \%$ makes it impossible for the user to be awarder the title of a Super Salesman status, which indicates high quality of service.
}

\subsection{Usability study}

\section{Usability study based on the website usage scenario}

The research was performed with 5 person focus group of potential RTV (multimedia)/AGD (domestic appliances) e-commerce website users. The following scenario, for the needs of usability study, was determined:

\section{Scenario of dishwasher purchase in e-commerce RTV/AGD website:}

Customer is searching for AAA class dishwasher, with relatively low noise level, program countdown possibility, $1 / 2$ input option, startup delay, possibility to wash large plates (movable basket, long manufacturer warranty. After the selection the customer purchases the product without logging in and expects credit card payment possibility.

The research results indicated that none of the researched websites allows the advanced search of products, which include standard parameters of the equipment. Such attempt was made, in limited scope, in the Allegro website, but the result of this search engine is not satisfactory. Neo24.pl and Electro.pl offer similar product comparison systems. Even though this solution does not allow quick product search, it allows performing detailed product comparison. It is important to emphasize that in every of researched websites searching for a product with specific features (without naming the manufacturer or price) is connected with slow and time-consuming searching through product group lists.

All websites have a considerable speed of reaching product groups by the user - selection of dishwashers was reached after 2 clicks. All websites allow adding products to the cart without the need to $\log$ in.

However, only Neo24 and Electro.pl allow performing the purchase without earlier user registration. Electro.pl has missing data for some of the products, what does not allow comparing them with other products. Neo24.pl website has contradictory information on the time of warranty, according to the information of the manufacturer. All websites allow performing purchases with credit cards.

The marks awarded in the partial research are:

- Agito.pl-2 points,

- Neo24.pl-3 points,

- Elektro.pl-4 points. 
Table 8. Visibility and opinion about selected websites connected with e-commerce

\begin{tabular}{|l|c|c|c|}
\hline \multicolumn{1}{|c|}{ Researched factor } & Agito.pl & Neo24.pl & Electro.pl \\
\hline Presence in Allegro.pl & NO & YES & NO \\
\hline Opinion in Allegro.pl & - & $\begin{array}{c}\text { shop sells products } \\
\text { via Allegro.pl, with } \\
93,6 \% \text { positive } \\
\text { comments }\end{array}$ & - \\
\hline Presence in Opineo.pl & YES & YES & YES \\
\hline Opinion in Opineo.pl & $\begin{array}{c}\text { score: } 9,0 / 10 \\
\text { votes: } 2595\end{array}$ & $\begin{array}{c}\text { score: } 8,8 / 10 \\
\text { votes: } 1515\end{array}$ & $\begin{array}{c}\text { score: } 9,6 / 10 \\
\text { votes: } 9661\end{array}$ \\
\hline Presence in Ceneo.pl & YES & YES & YES \\
\hline Opinion in Ceneo.pl & $\begin{array}{c}\text { score: } 4,5 / 5 \\
\text { votes: } 4422\end{array}$ & $\begin{array}{c}\text { score: } 4,5 / 5 \\
\text { votes: } 6495\end{array}$ & $\begin{array}{c}\text { score: } 4,5 / 5 \\
\text { votes: } 18178\end{array}$ \\
\hline
\end{tabular}

Table 9. Expert usability analysis results

\begin{tabular}{|l|c|c|c|}
\hline \multicolumn{1}{|c|}{ Researched factor } & Agito.pl & Neo24.pl & Electro.pl \\
\hline $\begin{array}{l}\text { Are the used colors tuned down, not } \\
\text { aggressive, relevant to presented content? }\end{array}$ & YES & YES & YES \\
\hline Is the navigation usable an efficient? & YES & YES & YES \\
\hline Does the product search work properly? & NO & NO & NO \\
\hline $\begin{array}{l}\text { Does the product comparison work } \\
\text { properly? }\end{array}$ & NO & YES & YES \\
\hline $\begin{array}{l}\text { Is the presented information } \\
\text { understandable? }\end{array}$ & YES & YES & YES \\
\hline $\begin{array}{l}\text { Does the system clearly inform the user } \\
\text { about his current position? }\end{array}$ & YES & YES & YES \\
\hline $\begin{array}{l}\text { Is the purchase procedure clearly } \\
\text { described? }\end{array}$ & YES & YES & YES \\
\hline $\begin{array}{l}\text { Is the product purchase procedure } \\
\text { undisturbed? }\end{array}$ & YES & YES & YES \\
\hline $\begin{array}{l}\text { Is it always known at which stage the user } \\
\text { is in the purchase process? }\end{array}$ & YES & YES & YES \\
\hline Are the help systems available? & 7 & 9 & 9 \\
\hline
\end{tabular}

\section{Expert usability analysis}

Website usability was evaluated with the usability criterion checklist elaborated on the basis of literature analysis, with particular use of „Nielsen's heuristics”. Elaboration was prepared in the form of checklist filled in for each website.

The marks awarded in the partial research are:

- Agito.pl - 4,2 points,

- Neo24.pl - 5,4 points,

- Elektro.pl - 5,4 points.
Total evaluation with the consideration of weights awarded in the usability (U) research is as follows:

- Agito.pl - 3,1 points,

- Neo24.pl - 4,2 points,

- Elektro.pl-4,7 points. 


\subsection{Accessibility study}

\section{Accessibility research at 1 level of WCAG W3C with the Cynthia validator}

Cynthia system, possible to access at the ContentQuality.com website, was used to perform the research. This system allows validating websites according to the compliancy with:

- Section 508 (fragment of "The Rehabilitation Act (29 U.S.C. 794d)" called "Electronic and Information Technology",

- WCAG 1.0 standard of W3C organization according to $1,2,3$ priorities.

Due to the fact that WCAG 1.0 standard, especially at level 1, is included in EU legislation according public administration website accessibility - it was selected for this research.

Result of the research indicated that none of the researched websites was compliant with all requirements of the firs (basic) level of WCAG W3C accessibility. The smallest failure (with relation to a selected criterion) concerned Agito.pl, other more considerable (with relation to many criteria) concerned Neo24.pl and Electro.pl websites.

The marks awarded in the partial research are:

- Agito.pl - 5 points,

- Neo24.pl-3 points,

- Elektro.pl - 3 points.

Table. 10. Accessibility research of accessibility research at level 1 of the WCAG W3C with the Cynthia validator

\begin{tabular}{|l|c|c|c|}
\hline & Agito.pl & Neo24.pl & Electro.pl \\
\hline $\begin{array}{l}\text { Number of spotted errors at the main page according } \\
\text { to the guidelines of priority 1 WCAG 1.0 }\end{array}$ & 3 & 8 & 9 \\
\hline
\end{tabular}

Table 11. Research of the triad for the crucial accessibility elements - expert analysis

\begin{tabular}{|l|c|c|c|}
\hline \multicolumn{1}{|c|}{ Researched factor } & Agito.pl & Neo24.pl & Electro.pl \\
\hline $\begin{array}{l}\text { Possibility to display the website in internet browsers } \\
\text { with different engines }\end{array}$ & 2 & 2 & 2 \\
\hline Site map in text version or website text version & 1 & 2 & 2 \\
\hline Possibility to change the website font size & 0 & 0 & 0 \\
\hline
\end{tabular}

Table 12. Total website evaluation result in V-U-A method

\begin{tabular}{|c|c|c|c|}
\hline Researched feature & Agito.pl & Neo24.pl & Electro.pl \\
\hline Visibility $(V)$ - weight 0,4 & 1,8 & 2,5 & 3,7 \\
\hline Usability (U) - weight 0,4 & 3,1 & 4,2 & 4,7 \\
\hline Accessibility (A) - weight 0,4 & 4,2 & 3,4 & 3,4 \\
\hline Total mark (0-6 scale) & 2,80 & 3,36 & 4,04 \\
\hline
\end{tabular}


The marks awarded in the partial research are:

- Agito.pl-3 points,

- Neo24.pl-4 points,

- Elektro.pl-4 points.

Total evaluation with the consideration of weights awarded in the visibility (V) research is as follows:

- Agito.pl-4,2 points,

- Neo24.pl-3,4 points,

- Elektro.pl-3,4 points.

\subsection{Total website evaluation result in V-U-A method research}

On the basis of visibility, usability and accessibility study complete evaluation of the feature combination, which characterizes researched websites, was elaborated. The evaluation is collected in table 12 .

\section{$7 \quad$ Summary}

Visibility, usability and accessibility issues of websites are more often present both in scientific literature and practical guidebooks. Usually these publications deal with these issues separately. The complex evaluation of factors, formulating the incoming website traffic, collection management methodology available also for MSP enterprises is lacking. Research results presented in the article indicate that the $\mathrm{B} 2 \mathrm{C}$ e-commerce sector of Polish market is using the visibility, usability and accessibility factors in order to improve the sales competitive position of the websites.

Fierce competition is especially visible in the scope of creation of website visibility. Whole spectrum of user reaching possibilities is used here, including positioning in web search engines and other forms of internet advertising. On the other hand, the example of Agito.pl shows the results of lack of interest in website visibility policy by the market leader (with relation to the number of visits). Polish e-commerce market looks much worse in terms of website usability and accessibility. Research websites definitely are difficult to operate by people who require higher website accessibility. There also major problems in usability in selected websites. The most important fact is that none of the websites allowed to realize the determined purchase scenario, based on standard customer behavior known from traditional shops. In one of the researched websites the obligatory registration is still required, what has a negative influence on the business, even though it is said to be a basic and typical usability problem. Results of the research performed on such small sample are difficult to generalize and relate to the whole $\mathrm{B} 2 \mathrm{C}$ e-commerce sector. However, this problem definitely needs more attention and should be researched in future studies.

\section{$8 \quad$ References}

[1] Bickerton P., Bickerton M., Pardesi U. - Cybermarketing. Butterworth-Heinemann, Kidlington 2000.

[2] Gąsiorkiewicz A. - Marketing internetowy w wyszukiwarkach jako narzędzie kreacji wartości biznesu [in] XI Konferencja Komputerowo Zintegrowane Zarządzanie. Zakopane 2008, pp. 338-345.

[3] Kalbach J. - Designing Web Navigation: Optimizing the User Experience. O'Reilly 2007.

[4] Kasperski M., Boguska-Torbicz A. - Projektowanie stron $W W W$. Użyteczność $w$ praktyce. Helion, Gliwice 2008.

[5] Kaushik A. - Web Analytics: An Hour a Day. John Wiley and Sons, New York 2007.

[6] Krug S. - Don't Make Me Think: A Common Sense Approach to Web Usability. 2nd ed., New Riders Press, 2005.

[7] Moran M., Hunt B. - Search Engine Marketing, Inc.: Driving Search Traffic to Your Company's Web Site. IBM Press, 2005.

[8] Moruń K. - Odpowiedzialność prawna za odestania $w$ Internecie [in] Przegląd Prawa Handlowego, No. 12, 2007.

[9] Nielsen J. - Enhancing the explanatory power of usability heuristics. Proc. ACM CHI'94 Conf., Boston 1994.

[10] Nielsen J. - Heuristic evaluation [in] Usability Inspection Methods (ed. Nielsen J., Mack R.L.). John Wiley \& Sons, New York 1994, pp. 25-62.

[11] Nielsen J., Loranger H. - Prioritizing Web Usability. New Riders Publishing, 2007.

[12] Strauss J., El-Ansary A.., Frost R. - E-Marketing (4 th Edition). Prentice-Hall, New Jersey 2005.

[13] Thatcher J., Burks M., Heilmann Ch., Henry S. L., Lauke P. H., Rutter R. - Web Accessibility: Web Standards and Regulatory Compliance. Friends od. ED, 2006. 